\title{
Comparison of thermal manikins to human thermoregulatory responses
}

\author{
Jonathan Power ${ }^{*}$, Andrew Baker, António Simões Ré \\ From 15th International Conference on Environmental Ergonomics (ICEE XV) \\ Portsmouth, UK. 28 June - 3 July 2015
}

\begin{abstract}
Introduction
Immersion suits are lifesaving appliances (LSA) designed to protect the wearer if they become accidently immersed in cold water by reducing the cold shock response and delaying the onset of hypothermia. Immersion suits are certified to both national and international standards; some of which require the thermal protective properties to be tested using humans or thermal manikins. The ethical nature of testing with humans has been questioned [1] due to the physically grueling nature of these tests, thus testing with manikins may be preferential. However, previous work has shown that discrepancies exist between thermal manikins and humans that could result in immersion suit selection that would benefit the former more than the latter who would ultimately use it [2]. This study investigated the thermoregulatory responses of humans and compared them to a thermal manikin while wearing immersion ensembles with insulation distributed in various configurations hypothesized to be beneficial to humans and manikins.
\end{abstract}

\section{Methods}

Eleven healthy males performed three, 3-hour immersion in $5{ }^{\circ} \mathrm{C}$ stirred water while wearing various immersion ensembles. The immersion ensembles consisted of standardized underclothing, an outer waterproof shell, and a custom-made closed cell neoprene inner liner with insulation distributed in three configurations: "Control" - insulation distributed evenly around the limbs and torso; "Human Beneficial" (HB) - insulation concentrated around the torso compared to the limbs; and "Manikin Beneficial" (MB) - insulation concentrated around the limbs compared to the torso. Mean skin temperature $\left(\mathrm{T}_{\mathrm{SK}}\right)$, mean skin heat loss (MSHL), gastrointestinal temperature $\left(\mathrm{T}_{\mathrm{GI}}\right)$, and oxygen consumption

\footnotetext{
* Correspondence: jonathan.power@nrc.ca

National Research Council of Canada, St. John's, NL, Canada
$\left(\mathrm{VO}_{2}\right)$ were measured throughout the immersions. A 23 zone thermal manikin (NEMO) was also immersed with the same three ensembles.

\section{Results}

For the humans, across all ensembles, there were no significant differences in the mean (SD) change in $\mathrm{T}_{\mathrm{SK}}$ (Control: $-4.5[0.6]{ }^{\circ} \mathrm{C}$; HB: $-4.5[1.0]{ }^{\circ} \mathrm{C}$; $\mathrm{MB}:-4.6[0.9]{ }^{\circ} \mathrm{C}$ ), MSHL at the end of the immersions (Control: 95.5[10.2] $\mathrm{W} \cdot \mathrm{m}^{-2}$; HB: $\left.101.9[8.2] \mathrm{W} \cdot \mathrm{m}^{-2} ; \mathrm{MB}: 102.0[8.8] \mathrm{W} \cdot \mathrm{m}^{-2}\right)$, change in $\mathrm{T}_{\mathrm{GI}}$ (Control: $-0.1[0.4]{ }^{\circ} \mathrm{C}$; $\mathrm{HB}$ : $-0.2[0.4]{ }^{\circ} \mathrm{C}$; MB: $-0.3[0.3]{ }^{\circ} \mathrm{C}$ ), and $\mathrm{VO}_{2}$ at the end of the immersion (Control: 515.7 [79.5] $\mathrm{mL} \cdot \mathrm{min}^{-1}$; HB: 538.9 [77.3] $\mathrm{mL} \cdot \mathrm{min}^{-}$ ${ }^{1}$; MB: $\left.565.3[101.2] \mathrm{mL} \cdot \mathrm{min}^{-1}\right)$. There were no significant differences in the clo value of the ensembles as measured by the humans (Control: 1.39[0.16] clo; HB: 1.28[0.13] clo; MB: 1.28[0.15] clo); and NEMO (Control: 1.09 clo; HB: 1.06 clo; MB: 1.09 clo).

\section{Discussion}

Our findings do not agree with the previous work [2] undertaken with lower levels of overall insulation in that we did not find any significant differences in change in deep body temperature $\left(\mathrm{T}_{\mathrm{GI}}\right)$ or $\mathrm{VO}_{2}$ when insulation was reduced over the torso compared to the limbs. As well, when insulation was reduced over the limbs compared to the torso, NEMO did not measure a large $(>10 \%)$ drop in clo. Initial results suggest that all three ensembles caused the same level of thermal stress in the humans, even though insulation was concentrated around the torso in $\mathrm{HB}$, and reduced around it in MB.

\section{Conclusion}

Higher overall insulation values may negate the differences in thermoregulatory and thermal responses of humans and manikins evoked by differences in regional insulation. 
Published: 14 September 2015

\section{References}

1. Barwood MJ, Tipton MJ: Surviving prolonged cold water immersion - An evaluation of immersion dry suit test performace standards. World Conference on Drowning Prevention. Vietnam; 2011.

2. Tipton MJ, Balmi PJ: The effect of water leakage on the results obtained from human and thermal manikin tests of immersion protective clothing. Eur J Appl Physiol Occup Physiol 1996, 72:394-400.

doi:10.1186/2046-7648-4-S1-A16

Cite this article as: Power et al.: Comparison of thermal manikins to human thermoregulatory responses. Extreme Physiology \& Medicine 2015 4(Suppl 1):A16.

Submit your next manuscript to BioMed Central and take full advantage of:

- Convenient online submission

- Thorough peer review

- No space constraints or color figure charges

- Immediate publication on acceptance

- Inclusion in PubMed, CAS, Scopus and Google Scholar

- Research which is freely available for redistribution

Submit your manuscript at www.biomedcentral.com/submit
C Biomed Central 